\title{
PENGARUH LIFE REVIEWTHERAPY TERHADAP KUALITAS HIDUP PADA DOMAIN PSIKOLOGIS PASIEN KANKER PAYUDARA YANG MENJALANI KEMOTERAPI DI RSI SULTAN AGUNG SEMARANG
}

\author{
Ismonah $^{\text {1); Aziz Oktasari Sihana }}{ }^{2)}$ \\ Program Studi S-1 Ilmu Keperawatan STIKES Telogorejo Semarang, Indonesia \\ ismonah@stikestelogorejo.ac.id
}

\begin{abstract}
ABSTRAK
Di Indonesia, angka kejadian kanker payudara berdasarkan diagnosis dokter meningkat dari $0,14 \%$ pada tahun 2013 menjadi $0.18 \%$ pada tahun 2018. Kanker payudara adalah pertumbuhan sel abnormal di daerah payudara yang dalam penanganannya dapat dilakukan kemoterapi. Kemoterapi tidak hanya memberikan efek positif tetapi juga memberikan efeknegatif terhadap kondisi psikologis pasien kanker payudara yaitu penurunan kualitas hidup pada domain psikologis. Upaya untuk meningkatkan kualitas hidup pada domain psikologis salah satunya dengan Life Review Therapy.Penelitian ini bertujuan untuk mengetahui pengaruh Life Review Therapy terhadap kualitas hidup pada domain psikologis pasien kanker payudara yang menjalani kemoterapi di RSI Sultan Agung Semarang. Rancangan penelitian menggunakan pra experimental design dengan one group pre-post-test without control group. Jumlah sampel dalam penelitian ini sebanyak 34 responden dengan teknik pengambilan sampel purposive sampling. Hasil penelitian menunjukkan kualitas hidup buruk pada domain psikologis sebelum intervensi 19 responden $(55.9 \%)$ dan setelah intervensi 8 responden (23.5\%). Hasil uji Wilcoxon menunjukkan bahwa Life Review Therapy berpengaruh terhadap kualitas hidup pada domain psikologis dengan $p=$ value 0.0001 . Berdasarkan hasil penelitian perawat dapat menerapkan terapi ini pada setiap pasien kanker payudara yang menjalani kemoterapi untuk meningkatkan kualitas hidup pada domain psikologis.
\end{abstract}

Kata Kunci: Kanker payudara, kemoterapi, kualitas hidup pada domain psikologis, Life Review Therapy

\begin{abstract}
In Indonesia, the incidence of breast cancer based on doctor's diagnosis increased from $0.14 \%$ in 2013 to $0.18 \%$ in 2018. Breast cancer is the growth of abnormal cells in the breast area which chemotherapy can handle. Chemotherapy not only has a positive effect but also has a negative effect on the psychological condition of breast cancer patients which is a decrease in quality of life in the psychological domain. Efforts to improve the quality of life in the psychological domain, one of which is Life Review Therapy. This study aims to determine the effect of Life Review Therapy on quality of life on the psychological domain of breast cancer patients undergoing chemotherapy at Sultan Agung Hospital in Semarang. The design of the study used a pre-experimental design with one group pre-posttest without control group. The number of samples in this study were 34 respondents with purposive sampling sampling technique. The results showed poor quality of life in the psychological domain before the intervention of 19 respondents (55.9\%) and after the intervention of 8 respondents $(23.5 \%)$. The Wilcoxon test results show that Life Review Therapy affects the quality of life in the psychological domain with $p=$ value. Based on the results of research, nurses can apply this therapy to every breast cancer patient who 0.0001 undergoes chemotherapy to improve the quality of life in the psychological domain.
\end{abstract}

Key words: Breast cancer, chemotherapy, quality of life in the psychological domain, Life Review Therapy 


\section{PENDAHULUAN}

Kanker adalah suatu penyakit yang diakibatkan oleh pertumbuhan sel-sel tubuh yang abnormal dan berubah menjadi sel kanker (Kresno, 2012). Global Burden of Cancer (GLOBOCAN) sebagai bagian dari International Agency for Research on Cancer (IARC) menetapkan beban kanker meningkat menjadi 18,1 juta kasus baru dan 9,6 juta kematian sedangkan sebanyak 627.000 wanita meninggal karena kanker payudara pada 2018 (WHO (2018). Data Riset Kesehatan Dasar tahun 2018 menunjukkan bahwa prevalensi kanker payudara di Indonesia berdasarkan diagnosis dokter meningkat dari 2013 sebanyak $0,14 \%$ menjadi $0,18 \%$ pada 2018 (Riskesdas, 2018). Profil Kesehatan Provinsi Jawa Tengah tahun 2013 memaparkan jumlah kasus kanker payudara di Jawa Tengah sebesar 4.761 kasus. Berdasarkan Profil Kesehatan Kota Semarang tahun 2016 tercatat 1.360 kasus kanker dan urutan pertama ditempati oleh kanker payudara yaitu 749 kasus. Data catatan keperawatan ruang Ma'wa RSI Sultan Agung dari bulan Januari-Desember tahun 2018 jumlah pasien kanker payudara rawat inap yang menjalani kemoterapi sebanyak 444 pasien, rata-rata perbulan sebanyak 37 pasien.

Kemoterapi merupakan terapi sistemik yang pengobatannya menggunakan zat kimia yang berfungsi untuk membunuh sel kanker dan dapat mencapai sel kanker yang telah menyebar jauh atau metastase ke tempat lain (Azwar, 2012). Kemoterapi tidak hanya memberikan efek positif tetapi juga memberikan efeknegatif terhadap kondisi psikologis pasien kanker payudara yang menjalani kemoterapi yaitu kualitas hidup pada domain psikologis.

Oleh karena itu perlu adanya suatu tindakan untuk membantu pasien mengurangi dampak dari kemoterapi, khususnya dampak psikologis untuk meningkatkan kualitas hidup pada domain psikologis salah satunya adalah Life Review Therapy. Life Review Therapy akan membawa seseorang untuk bisa lebih mengenal siapa dirinya dan dengan recall tersebut dapat mempertimbangkan untuk dapat mengubah kualitas hidup pada domain psikologis menjadi lebih baik dibandingkan sebelumnya (Setyoadi \& Kusharyadi, 2011). bahwa ada pengaruh Life Review Therapy terhadap kualitas hidup lansia di UPT Pelayanan Sosial Lanjut Usia Kabupaten Bondowoso dengan $\mathrm{p}$ value 0,028. Hasil penelitian Muhimatulaili (2017) juga menunjukkan adanya pengaruh Life Review Therapy terhadap kualitas hidup pada pasien gagal ginjal kronik yang menjalani hemodialisis di RSI Sakinah Mojokerto dengan $\mathrm{p}$ value 0,000 . Hal ini juga diperkuat dengan penelitian Sharif, et al., (2017) yang menjelaskan bahwa Life Review Therapy efektif digunakan untuk meningkatkan kualitas hidup kehidupan akhir lansia di Pusat Rehabilitasi Lansia dengan $\mathrm{p}$ value $<0,05$.

Berdasarkan hasil penelitian tersebut, peneliti berasumsi bahwa Life Review Therapy juga bermanfaat untuk meningkatkan kualitas hidup pada domain psikologis pasien kanker payudara yang menjalani kemoterapi. Hal ini memperkuat pentingnya dilakukan penelitian tentang "Pengaruh Life Review Therapy terhadap Kualitas Hidup pada Domain Psikologis Pasien Kanker Payudara yang Menjalani Kemoterapi di RSI Sultan Agung Semarang".

\section{METODE PENELITIAN}

Penelitian ini termasuk dalam jenis penelitian pra experimental design yaitu dengan bentuk rancangan one group pre post without control group, di mana pada rancangan ini peneliti tidak menggunakan kelompok kontrol, tetapi sebelumnya sudah dilakukan observasi pre test (sebelum diberikan intervensi) yang memungkinkan menguji perubahan-perubahan yang terjadi setelah adanya perlakuan (Notoatmodjo, 2012). Responden penelitian ini adalah 34 pasien penderita kanker payudara yang menjalani kemoterapi yang ditetapkan dengan teknik purposive sampling. Penelitian dilakukan dari tanggal 12 - 24 April 2019.

\section{HASIL DAN PEMBAHASAN PENELITIAN}

\section{Analis is Univariat}

Tabel 1. Distribusi frekuensi responden berdasarkan karakteristik responden di RSI Sultan Agung Semarang pada tanggal 12 - 24 April 2019

Pernyataan ini didukung penelitian Aini, Sasmiyanto dan Asih (2014) memaparkan 


\begin{tabular}{|c|c|c|c|}
\hline \multicolumn{2}{|c|}{ Variabel } & $\begin{array}{l}\text { Frekuensi } \\
\text { (f) }\end{array}$ & $\begin{array}{c}\text { Persentase } \\
(\%)\end{array}$ \\
\hline \multirow[t]{3}{*}{1} & Jenis Kelamin & & \\
\hline & a. Laki-laki & 1 & 2,9 \\
\hline & b. Perempuan & 33 & 97,1 \\
\hline \multirow[t]{6}{*}{2} & Usia & & \\
\hline & $\begin{array}{l}\text { a. Dewasa awal } \\
\text { (26-35 tahun) }\end{array}$ & 1 & 2,9 \\
\hline & $\begin{array}{l}\text { b. Dewasa akhir } \\
\text { (36-45 tahun) }\end{array}$ & 11 & 32,4 \\
\hline & $\begin{array}{l}\text { c. Lansia awal } \\
\text { (46-55 tahun) }\end{array}$ & 12 & 35,3 \\
\hline & $\begin{array}{l}\text { d. Lansia akhir } \\
\text { (56-65 tahun) }\end{array}$ & 7 & 20,6 \\
\hline & $\begin{array}{l}\text { e. Manula } \\
(66-\text { ke atas }) \\
\end{array}$ & 3 & 8,8 \\
\hline \multirow[t]{6}{*}{3} & Pendidikan & & \\
\hline & $\begin{array}{ll}\text { a. } & \text { Tidak } \\
& \text { sekolah }\end{array}$ & 1 & 2,9 \\
\hline & b. $\mathrm{SD}$ & 22 & 64,7 \\
\hline & c. SMP & 5 & 14,7 \\
\hline & d. SMA & 5 & 14,7 \\
\hline & e. PT & 1 & 2,9 \\
\hline \multirow[t]{6}{*}{4} & Pekerjaan & & \\
\hline & $\begin{array}{l}\text { a. Ibu Rumah } \\
\text { Tangga } \\
\text { (IRT) }\end{array}$ & 17 & 50 \\
\hline & b. Buruh & 9 & 26,5 \\
\hline & c. Wiraswasta & 7 & 20,6 \\
\hline & d. PNS & 0 & 0 \\
\hline & e. Lainnya & 1 & 2,9 \\
\hline \multicolumn{2}{|c|}{ Total } & 34 & 100 \\
\hline
\end{tabular}

Berdasarkan tabel 1. dapat diketahui bahwa mayoritas responden kanker payudara yang menjalani kemoterapi di RSI Sultan Agung Semarang berjenis kelamin perempuan sebanyak $97,1 \%$ dan terdapat 2,9\% laki-laki yang menderita kanker payudara. Wanita adalah faktor resiko pasti terkena kanker payudara. Namun, kanker payudara juga dapat terjadi pada pria, meskipun jarang atau sekitar 1\% (Hari, 2016). Beberapa faktor penyebab terjadinya kanker payudara antara lain faktor hormonal dan faktor genetik (Lincoln \& Wilensky, 2008). Faktor hormonal, khususnya hormon estrogen yang cenderung tidak stabil karena beragam faktor, terutama kandungan bahan kimia pada makanan seperti bahan pengawet, pewarna kimia, pemanis buatan, dan makanan yang banyak mengandung kolesterol (Firmana, 20117). Hal ini menyebabkan perubahan dalam ekspresi gen tertentu yang dapat menstimulasi pertumbuhan sel abnormal seperti sel kanker (Hari, 2016). Adapun faktor lain yaitu usia yang berkaitan dengan insiden kanker payudara.
Hasil penelitian menunjukkan bahwa mayoritas responden berusia lansia awal (46-55 tahun) sebanyak $35,3 \%$. Semakin bertambahnya usia merupakan salah satu faktor risiko kanker payudara, karena pengaruh pajanan hormonal dalam waktu lama terutama hormon estrogen pasca menopause (Lincoln \& Wilensky, 2008). Semakin tua usia seseorang saat awal menopause maka memiliki risiko lebih besar terkena kanker payudara dibandingkan wanita yang mengalami menopause lebih muda. Selain itu, pada lanjut usia daya surveilans imunitas terhadap sel mutan melemah, maka insiden kanker meningkat seiring pertambahan usia (Desen, 2011). Adapun faktor lain yaitu pendidikan yang berkaitan dengan insiden kanker payudara.

Hasil penelitian menunjukkan bahwa mayoritas responden berpendidikan dasar sebanyak 35,3\%. Menurut Mangan (2009), penyakit kanker dapat menyerang siapapun dan dari golongan mana pun. Hal ini juga didukung juga oleh Ariani (2015), yang menyatakan bahwa penyakit kanker dapat menyerang semua kelompok, dari masyarakat miskin sampai kaya dan semua strata pendidikan dari tidak sekolah sampai perguruan tinggi. Hal ini dikarenakan risiko insiden kanker payudara mungkin disebabkan karena adanya faktor-faktor lain yang dapat memberikan efek negatif pada kesehatan seperti faktor gaya hidup sebelum terjadinya sakit dan faktor kebetulan (Smeltzer \& Bare, 2014). Adapun faktor lain yaitu pekerjaan yang berkaitan dengan insiden kanker payudara.

Hasil penelitian menunjukkan bahwa mayoritas responden yaitu ibu rumah tangga sebanyak 50\%. Menurut Arifa, Azam dan Handayani (2017) bahwa tidak ada hubungan yang bermakna antara pekerjaan dengan kejadian suatu penyakit tertentu. Hal ini dikarenakan risiko insiden kanker payudara mungkin disebabkan karena adanya faktor-faktor lain yang dapat memberikan efek negatif pada kesehatan seperti faktor stres, faktor gaya hidup dan akitifitas serta faktor kebetulan (Smeltzer \& Bare, 2014).

Tabel 2. Nilai kualitas hidup pada domain psikologis responden kanker payudara yang menjalani kemoterapi sebelum dan setelah diberikan Life Review Therapy di RSI Sultan 
Agung Semarang pada tanggal 12 - 24 April 2019

\begin{tabular}{lcccc}
\hline $\begin{array}{c}\text { Kualitas } \\
\text { Hidup } \\
\text { pada }\end{array}$ & \multicolumn{2}{c}{$\begin{array}{c}\text { Pre } \\
\text { Intervensi }\end{array}$} & \multicolumn{2}{c}{$\begin{array}{c}\text { Post } \\
\text { Intervensi }\end{array}$} \\
\cline { 2 - 6 } $\begin{array}{c}\text { Domain } \\
\text { Psikologis }\end{array}$ & (f) & (\%) & (f) & (\%) \\
\hline Buruk & 19 & 55,9 & 8 & 23,5 \\
Baik & 15 & 44,1 & 26 & 76,5 \\
\hline Total & 34 & 100,0 & 34 & 100,0 \\
\hline
\end{tabular}

Berdasarkan Tabel 2. dapat diketahui bahwa kualitas hidup buruk pada domain psikologis sebelum intervensi 19 responden $(55,9 \%)$ dan setelah intervensi 8 responden $(23,5 \%)$.

Kualitas hidup pada domain psikologis menurut WHO (1996, dalam Nursalam, 2013) merupakan konsep analisis dari kemampuan individu untuk mendapatkan hidup yang normal terkait dengan persepsi secara individu mengenai tujuan, harapan, standar dan perhatian secara spesifik terhadap keadaan mental individu. Keadaan mental mengarah pada mampu atau tidaknya individu menyesuaikan diri terhadap berbagai tuntutan perkembangan sesuai dengan kemampuannya, baik tuntutan dalam diri maupun dari luar. Tuntutan itu mencakup kesejahteraan psikologis yaitu penampilan tubuh, perasaan negatif, perasaan positif, spiritualitas agama atau keyakinan pribadi, penghargaan diri dan berpikir, belajar, memori dan konsentrasi (Nursalam, 2013).

Berdasarkan Teori Kubler-Ross (1969, dalam Gregory, 2019) pasien dengan penyakit kronik atau terminal menolak bahwa kematian akan terjadi dalam hidupnya. Hal ini dapat menstimulasi munculnya reaksi marah dan dendam. Seiring bejalannya waktu, mereka berpikir bahwa kematian dapat ditunda. Namun, ketika seseorang tidak dapat mengontrol penolakan terhadap penyakitnya, ketika kondisi fisiknya semakin memburuk hal ini menyebabkan pasien menjadi pasrah atau mati rasa. Pasien yang masih memiliki banyak waktu (belum menghadap kematian) dan mendapat pertolongan perhatian dalam masamasa sulit yang dialaminya, dia akan masuk ke masa dimana dia tidak marah ataupun depresi dengan takdir yang akan dihadapinya, fase inilah yang disebut fase penerimaan (acceptance) (Kubler-Ross, 1969, dalam Gregory, 2019).

Halini didukung penelitian Rochmawati(2015) memaparkan semua responden pasien kanker payudara di RSUD Dr. Moewardi terjadi penurunan kualitas hidup pada dimensi psikologis, semua responden $(100 \%)$ merasa sedih akibat dari pengobatan yang lama. Berdasarkan penjabaran diatas, dapat disimpulkan bahwa pada tahap awal pasien kanker payudara yang menjalani pengobatan (kemoterapi) pasien belum bisa menerima atas penyakitnya, marah dengan kejadian yang ada dan merasa sedih dengan kejadian yang dialami. Namun setelah diberikan Life Review Therapy, terjadi perubahan respon psikologis sehingga dapat berpengaruh terhadap kualitas pada domain psikologisnya.

\section{Analis is Bivariat}

Uji statistik pengaruh Life Review Therapy terhadap kualitas hidup pada domain psikologis pasien kanker payudara yang menjalani kemoterapi disajikan dalam tabel 3 sebagai berikut:

Tabel 3. Pengaruh Life Review Therapy terhadap kualitas hidup pada domain psikologis pasien kanker payudara yang menjalani kemoterapi di RSI Sultan Agung Semarang pada tanggal 12 - 24 April 2019

\begin{tabular}{ccccc}
\hline $\begin{array}{c}\text { Variabel } \\
\text { Kualitas } \\
\text { Hidup } \\
\text { pada } \\
\text { Domain }\end{array}$ & Median & Min & Max & $\begin{array}{c}\text { P } \\
\text { value }\end{array}$ \\
Psikologis & & & & \\
\hline Sebelum & 50 & 19 & 75 & 0,0001 \\
Sesudah & 66 & 31 & 88 & \\
\hline
\end{tabular}

Berdasarkan tabel 3. dapat diketahui bahwa hasil nilai median sebelum intervensi didapatkan 50 dengan nilai minimal 19 dan nilai maksimal 75. Sedangkan hasil nilai median setelah intervensi meningkat menjadi 66 dengan nilain minimal 31 dan nilai maksimal 88. Hasil $p$-value $=0,0001(\leq 0,05)$, berarti ada pengaruh Life Review Therapy terhadap kualitas hidup pada domain psikologis pasien kanker payudara yang menjalani kemoterapi di RSI Sultan Agung Semarang.

Life Review Therapy pada fase mengingat kembali kejadian atau pengalaman masa lalu 
yang menyenangkan yang akan dibentuk sebagai topik yang baik (Manurung, 2016). Saat berpikir tentang hal-hal yang membahagiakan, otak melepaskan hormon-hormon yang baik salah satunya yaitu hormon beta-endorpfin (hormon kebahagiaan) yang dilepaskan oleh otak. Fungsi dari hormon beta-endorfin ini dapat memperbaiki suasana hati seseorang, memotivasi semangat untuk beraktifitas dan menyakinkan diri. Jika hormon ini dilepaskan dalam jumlah cukup, efeknya tidak hanya pada otak, tetapi sampai keseluruh tubuh dan hal ini berguna untuk meningkatkan kepuasan hidup seseorang (Haruyama, 2015).

Kepuasan hidup seseorang didapatkan saat adanya hubungan antara pikiran dan tubuh. Saat seseorang melepas emosi-emosi positif berupa kasih terhadap jiwanya sendiri, jantung akan mengomunikasikan pesan sejahtera pada tubuh melalui pelepasan hormon-hormon dan neurotransmitter yang menolong (Haruyama, 2015). Ketika seseorang merasa puas dan bahagia, jantung berdetak sangat lambat, memberitahukan pada seluruh sistem saraf bahwa orang tersebut dalam keadaan baik. Jantung memiliki kemampuan untuk mempengaruhi setiap sistem tubuh yang lain untuk mengikuti ritmenya. Jantung yang berada dalam keadaan damai dan penuh kasih akan mengomunikasikan hormon ke seluruh tubuh (Pradiansyah, 2016, hlm. 125).

Hal ini sejalan dengan penelitian Wren (2017) memaparkan bahwa Life Review Therapy berpengaruh terhadap peningkatkan kualitas hidup lansia di panti jompo. Hal ini dibuktikan dengan peningkatan skor index- $Z$ pre intervensi yaitu $12(\mathrm{SD}=7,5)$ dan skor post intervensi yaitu $21(\mathrm{SD}=11,6)$. Pemberian terapi dilakukan seminggu sekali dalam rentang waktu 6 minggu (Wren, 2017, hlm. 11). Hasil penelitian mengenai Life Review Therapy juga diperkuat dengan penelitian Lin (2010) memaparkan bahwa Life Review Therapy menghasilkan perubahan positif skor kualitas hidup diukur dengan pengukuran kompleks multi-dimensi. Hal ini dibuktikan dari hasil skor mean kelompok intervensi sebelum diberikan Life Review Therapy didapatkan hasil 3,10 dan meningkat menjadi 3,72 setelah diberikan Life Review Therapy (Lin, 2010).

Peningkatan kualitas hidup domain psikologis ini juga akan membuat seseorang mempunyai harga diri yang positif dan mencegah terjadinya rendah diri. Hal ini sesuai dengan hasil penelitian yang dilakukan oleh Narulita (2017) bahwa hasil uji statistik didapatkan nilai $\mathrm{p}$ value $=0,000$, yang berarti ada perbedaan yang bermakna rata-rata perubahan harga diri, sehingga memberikan bukti bahwa life review therapy mampu memberikan dampak yang bermakna pada kualitas hidup sehingga pasien tidak merasakan harga diri rendah.

Berdasarkan penjabaran tersebut, dapat disimpulkan bahwa penelitian ini dan penelitian sebelumnya menyebutkan bahwa Life Review Therapy berpengaruh terhadap kualitas hidup. Hal ini dikarenakan Life Review Therapy pada penelitian ini mampu membantu pasien kanker payudara yang menjalani kemoterapi untuk menilai kehidupan yang telah dilaluinya. Sehingga penderita dapat merasakan kepuasan atas kehidupannya.

Hasil ini sejalan dengan pendapat Kushariyadi (2011) yang mengatakan bahwa suatu proses life review therapy dengan Standar Prosedural Operasional yang baik akan mengurangi depresi dan meningkatkan kepercayaan diri, kesejahteraan atau kesehatan psikologis, dan kepuasan hidup. Terapi life review adalah upaya untuk membantu seseorang untuk mengaktifkan ingatan jangka panjang dimana akan terjadi mekanisme recall tentang kejadian pada kehidupan masa lalu hingga sekarang, dengan cara ini, lansia akan lebih mengenal siapa dirinya dan dengan recall tersebut, lansia akan mempertimbangkan untuk dapat mengubah kualitas hidup menjadi lebih baik dibandingkan dengan sebelumnya

\section{SIMPULAN}

Life Review Therapy berpengaruh terhadap kualitas hidup pada domain psikologis pasien kanker payudara yang menjalani kemoterapi di RSI Sultan Agung Semarang dengan $p$ value $=0,0001$.

\section{SARAN}

Peneliti selanjutnya dapat menambahkan kelompok kontrol dan perlu memperhatikan faktor-faktor yang mempengaruhi kualitas hidup pada domain psikologis penderita serta menggali pengaruh Life Review Therapy tidak hanya terhadap pasien kanker payudara yang menjalani kemoterapi tetapi disarankan juga untuk pasien dengan penyakit kronik lainnya. 


\section{DAFTAR PUSTAKA}

Aini, M.N., Sasmiyanto., \& Asih, S.W. (2014). Pengaruh Life Review Therapy Terhadap Kualitas Hidup Lansia di Dinas Unit Pelaksana Teknis Pelayanan Sosial Lanjut Usia Kabupaten Bondowoso

Alam, S. (2017). Gambaran Kualitas Hidup Pasien Kanker Payudara di RSUD Panembahan Senopati Bantul

Ariani, S. (2012). Stop Kanker. Yogyakarta: Istana Media

Arifa, S.I., Azam, M., \& Handayani, O.W.K. (2017). Faktor yang berhubungan dengan kejadian penyakit ginjal kronik pada penderita hipertensi di Indonesia. Jurnal MKMI. Volume 13 Nomor 4

Azwar, B. (2012). Buku Panduan Pasien Kemoterapi. Jakarta: Dian Rakyat

Desen, W. (2011). Buku Ajar Onkologi Klinis. Edisi 2. Jakarta:FKUI

Firmana, D. (2017). Keperawatan Kemoterapi. Jakarta: Salemba Medika

Gregory, C. (2019). The Five Stage of Grief. https://www.psycom.net/depression.ce ntral .grief.html/, diperoleh 15 Mei 2019

Hari, D. (2016). Kanker Payudara Rentan Menyerang Wanita dengan Imunitas Rendah. http://rspremiersurabaya.com/kankerpayudara-rentan-menyerang-wanitadengan-imunitas-rendah/, diperoleh 27 Mei 2019

Haruyama, S. (2015). The Miracle of Endorphin. Jakarta: Qanita

Kresno, S. (2012). Ilmu Dasar Onkologi. Jakarta: FKUI

Kushariyadi. (2011). Terapi modalitas keperawatan pada klien psikogeriatrik. Jakarta: Salemba Medika.
Lin, L. J. (2010). Impact of the Revised Life Review Program on Quality of Life for Residents with Alzheimer's Disease in South Taiwan's Long Term Care Facilities.https://conservancy.umn.edu /bitstream/handle/11299/61955/Lin_u mn_0130E_10999.pdf?sequence $=1 \&$ is Allowed=y, diperoleh 18 Mei 2019

Lincoln, J., \& Wilensky. (2008). Kanker Payudara Diagnosis dan Solusinya. Jakarta: Prestasi Pustakaraya

Mangan, Y.(2009). Solusi Sehat Mencegah dan Mengatasi Kanker. Jakarta:Agromedia Pustaka

Manurung, N. (2016). Terapi Reminiscence. Jakarta: Trans Info Media

Muhimatulaili, D. (2017). Pengaruh Life Review Therapyterhadap Spiritual dan Kualitas Hidup Pasien Penyakit Ginjal Kronik yang Menjalani Hemodialisis di RSI Sakinah Mojokerto

Nati Aswanira, Rumentalia, Vausta, Efek Life Review Therapy Terhadap Depresi Pada Lansia Jurnal Keperawatan Indonesia, Vol. 18, No. 3, November 2015, hal 139-142 http://jki.ui.ac.id/index.php/jki/artic le/ view/416/523

Notoatmodjo, S. (2012). Metodologi Penelitian Kesehatan. Jakarta: Rineka Cipta

Nursalam. (2013). Metodologi Penelitian Ilmu Keperawatan Edisi 3. Jakarta: Salemba Medika

Pradiansyah, A. (2016). Laws of Happiness. Jakarta: PT Integritas Lestari Manajemen

Profil Kesehatan Kota Semarang. (2016). Profil Kesehatan Kota Semarang 2016. http://dinkes.semarangkota.go.id/asset/ upload/Profil/Profil $\%$ 20Kesehatan $\% 2$ 02016\% 20(OK).pdf, diperoleh tanggal 2 Desember 2018

Profil Kesehatan Provinsi Jawa Tengah. (2013). Profil Kesehatan Provinsi Jawa Tengah 
2013.http://www.depkes.go.id/resourc es/download/profil/PROFIL_KES_PR OVINSI_2013/13_Prov_Jateng_2013. pdf,diperoleh tanggal 2 Desember 2018

Riskesdas 2018. (2018). Hasil Utama Riskesdas 2018. Jakarta Selatan: Kementrian Kesehatan RI

Rochmawati, D. (2015). Kualitas Hidup Pasien $\mathrm{Ca}$ Mammae yang Menjalani Kemoterapi di RSUD Dr. Moewardi

Setyoadi., \& Kusharyadi. (2011). Terapi Modalitas Keperawatan pada Klien Psikogeriatrik. Jakarta: Salemba Medika

Sharif, F., Jahanbin, I., Amirsadat, A., \& Moghadam, M.H. (2017). Effectiveness of Life Review Therapy on Quality of Life in the Late Life at Day Care Centers of Shiraz Iran

Smeltzer, S.C., \& Bare, B.G. (2013). Buku Ajar Keperawatan Medikal Bedah (Handbook for Brunner \& Suddarth's Textbook of Medical-Surgical Nursing), Edisi 8, Volume 1. Jakarta: EGC
World Health Organization. (2018). World Health Organization - International Agency for Research on Cancer. http:/gco.iarc.fr/, diperoleh tanggal 3 Desember 201

Wren, R. (2016). Effect of life review on quality of life for older adults living in nursing homes.http//dx.doi.org/10.1080/02703 181.2016.1268236, diperoleh 18 Mei 2019 